\title{
CASE-BASED STUDY ON STRATEGIES OBTAINED IN TEACHING ENGLISH LANGUAGE TO FIRST YEAR ENGINEERING STUDENTS
}

\author{
Rinki Sanyal, D. Amani, K. Chandrakala \\ Assistant Professor, Department of Science \& Humanities, \\ St. Martin's Engineering College, Dhulapally, Secunderabad - 500100
}

\begin{abstract}
This paper presents a teacher's actual experience of teaching grammar and the nuances of English Language to aspiring engineers. Teachers encounter various obstacles on daily basis while interacting with their students. My paper, attempts to present some real life case based experience of a teacher. A teacher should always keep in mind that neither our emotional or behavioral disorder leave any negative impact on our students. As a teacher we have to understand the linguistically and culturally diverse background of the students. A teacher, has said is a friend, philosopher and guide and in real life we should be able to do so. First of all, a teacher should understand the constrains which a student might face after entering a big institution and the dilemma he/she faces while interacting with teachers or friends. My paper also discusses that a teacher should treat each and every student as their own family members, we should not restrict ours hours of interaction till the college hours but we should be with them in several networking sites where they can open up and this can help a student to express the difficulties in learning the language. According to Clay P. Bedford, " You can teach a student a lesson for a day, but if you teach him to learn by creating curiosity, he will continue the learning process as long as he lives." My attempt is to suggest some practical ways where the learning of a second language will be much more interesting and hence inculcate in them the competitive spirit and desire for high status job. Therefore, it is the responsibility of a teacher not only to complete the syllabus but to understand a student's need, problem and help the student in changing his/her attitude towards learning the language by implementing some innovative strategies to meet the needs of different learners.
\end{abstract}

Key Words: English, language, skills.

\section{INTRODUCTION}

Every teacher has his/her own strategy to enhance the ability of their students. Mc Donough defines strategy as an articulated plan for meeting particular type of problems, while Bialystok says that strategies are related to solutions in specific ways and they are productive in solving the problem for reasons. According to H.H. Stern, strategy is a plan of action and good language learning needs strategies of experimentation and planning with the object of developing the new language into an ordered system and revising this system progressively by constantly searching for meaning and willingness to practice. Hence, a strategy in teaching language is a plan of action used by a teacher or the university to break the barrier or fear of learning a foreign language.

I, personally use some strategy to teach English Language to first year Engineering students. They are:

1) Motivational Strategy

2) Technical Strategy

All teachers should have the knowledge to recognize the problem and need of the learner. A learner may face problem at word formation, pronunciation, phrases, sentence construction, listening, reading, in expressing while writing or so forth. As a teacher we have to closely observe each and every student and identify where the problem exists. Now a day most of the teachers are using NPL, i.e. Neuro Linguistic Programming. It is a psychological approach that involves analyzing strategies used by successful individuals and applying them to reach a personal goal. So when learning occurs naturally, the fear and the sense of losing in front of fellow mates disappear. This technique helps every student to relax at the beginning of a session and it increases their learning ability. To make our learners emotionally calm and mentally alert we teachers do several activities in classroom like chatting with 


\section{International Journal of Engineering Applied Sciences and Technology, 2020 \\ Vol. 4, Issue 12, ISSN No. 2455-2143, Pages 231-234 \\ Published Online April 2020 in IJEAST (http://www.ijeast.com)}

students on a recent movie, or asking them to express their viewpoints on the present situation of the country or sometimes how they are feeling after joining a prestigious institution. May be one or two hours of the class may go wasted in the chit chat but in this way we can understand our students in a much better way and we can analyze which strategy befits the learner. So, now if I come to motivational technique, unless and until we know our students, their lacuna, we as a teacher won't be able to motivate them. Further I will discuss some real incidence where a student has an urge to learn the language or he/she aspires to get a white-collared job but the difficulties which he/she is facing in college hostel regarding food, atmosphere or language barrier is hindering the learner to focus on his/her studies. There are some cases where a student is very good in writing the language with proper sentence structure and grammar but is very poor in communication. He/She might be afraid about the response of fellow mates which a teacher should take care and motivate the bubbling young mind in the right track.

The next strategy is technology, as per the university norms all colleges are equipped with multi-media labs, but what do students do there and we as teachers should follow some strategies to make the multimedia session interactive and interesting too. Students just put on their headsets and listen to the sounds or dialogues but are all the students able to understand those foreign accents, for the sake of the class some just keep quite. I personally ask them to bring newspaper and make them to read as they are listening to the sounds in those accents, they fail, they laugh but they find it interesting. We should make them realize that continuously reading magazines, books, newspaper and listening to news, $\mathrm{BBC}$ radio clips, tapes, watching movies might help them to pronounce the word $\mathrm{s}$ in a much more proper way and in the process enriches their listening skills. We should make them realize that no one is perfect in this world, but the endeavor to be perfect is worthy.

\section{DISCUSSION}

In view of teaching in several engineering colleges in Hyderabad, I encountered with students from diverse background and even foreign students from Sudan and Nepal. I experienced their fear, anxiety in expressing in English and I also encountered some students who are least bothered to master the language which I will discuss in cases below.

\section{Case Study 1:}

Background - An eighteen-year-old boy from a village of Warangal district was admitted to one of the prestigious engineering institutes in Hyderabad.
Strategy - The student used to sit at the penultimate bench of the class from the very first day. As he was from a village background, it was very hard for him to cope with the city culture and specially to face students from English medium background. As usual I didn't notice him at the very first day, but as my strategy, I always use the first week of the class to know my students, so while interacting I came to know that his father is a farmer and they had spent all their savings to send him to such a premium institution. He was good at other subjects but his English was not up to the mark, I would rather say, his English was not so polished to make him saleable in the market and clear his parent's debt. When I informed him that with this English it is not possible for him to crack the interview, so he said if it is not possible he will go back to village and continue farming. Now here comes the vital role of a teacher, especially a mentor. I asked him that he should go back now, instead of spending the money for the next four years, but he said he want to give a try. So, I told him okay, let's together give a try and the whole class promised to be with him. He started mingling with all his fellow mates, I shared my whatsapp number with him and when I reach home, as an elder sister I used to ask him about the life in hostel and he used to type in English, meanwhile I used to correct spellings, sentence formation and gave him tips on how to improve.

After a month he came to the middle bench of the class and he also started participating in group discussion and debate. Slowly and slowly his writing skills improved and listening skills were improved in CALL Lab. His fear, anxiety gradually disappeared and he opened up and at the end of 1st year, his English was quite good but I didn't lose touch with my students till the 4 th and some are still in contact. I provided him BBC news tapes, recording of great personalities and other learning aids which can help him to improve and now that meek and introvert student of mine is placed with an attractive package.

Conclusion - A teacher should sometime evaluate a student mind also.

\section{Case Study 2:}

Background - A 22 years old student from Sudan was admitted and was placed in my class.

Strategy - This student of mine was in several problems. First of all, he came to a foreign land where climate, food and each and everything was new to him. Secondly he was much elder than his mates. Learning or focusing to learn a new language was a secondary problem to him rather than to get accustomed to the new land. When I interacted with him, I came to know that the education system in 


\section{International Journal of Engineering Applied Sciences and Technology, 2020 \\ Vol. 4, Issue 12, ISSN No. 2455-2143, Pages 231-234 \\ Published Online April 2020 in IJEAST (http://www.ijeast.com)}

South Sudan is quite poor. Formation of sentence or writing paragraphs was quite far from him as he was unable to spell simple words like 'giraffe' or 'football', etc. Parts of speech, articles, preposition were in the long run. As a foreign student he has to sit in an exam conducted by Govt. of India, like we Indians have to sit for TOEFL or GRE to study abroad. I downloaded the total syllabus, brought some Indian school kids English books of standard one and two, and started teaching him each and everyday new words along with pictures because medium of communication between me and my student was only English and he was unable to express for which pictures was helpful. One month went on in learning spellings. Then came the Herculean task of teaching him grammar for which I resorted to Wren and Martin. 3-4 days I use to spare for each topic. In an English movie called " Notting Hill", the protagonist said, " Today's newspaper is tomorrow's waste paper", but for me newspaper was of great respite. I used to take some newspaper reporting and ask this student to mark all the parts of speech, articles and asked him to observe the usage of preposition. Then I tought him to form sentence in dialogue format, gradually I asked him to write 34 lines about his native, friends, etc. I procured for him story books with simple words and sentence structure, gradually his interest grew, his fear of being embraced among friend vanished, he started to communicate and meanwhile he cleared his exam. Presently he is pursuing his MBA and is quite good in communication.

Conclusion - A teacher should try his/her best to support the student.

\section{Case Study 3:}

Background - An 18-year-old girl from Hyderabad, admitted into Engineering as forced by her parents and she is least bothered about learning.

Strategy - This type of student is quite hard to handle. First of all, this girl doesn't want to express, she was an introvert. After a week, I came to know that she is interested in a beautician course and not engineering. Her viewpoint is that despite doing engineering she will be married off and her husband will make her to sit at home. So she doesn't want to waste her time in studies, she just wants to enjoy college and hostel life. Now, if I say about her efficiency in English Language, then she can somehow manage to speak but proper grammar and sentence construction was lacking. First of all, as a teacher, I have to calm her mentally, fetch her attention into studies and then have to talk about English. So I kept on counselling her for a month saying that if she becomes a beautician also, English is mandatory to handle posh and elite clients. Journals, western magazines will be easy for her to follow if she is good at English. Slowly she regained her interest in the language and started writing small healthy and beauty tips for college whatsapp group. This enhanced her writing skills. I provided her links of beauty journals and she started reading it voraciously and I asked her to make vocabulary stock, which ever word is unknown to her she used to write it in her note book along with the meaning, and every week she used to revise it. Her English was improving, in the CALL Lab she used to be inattentive, so I said listening is a part of understanding your clients, so here also I captured her attention. Now the semester approached, she failed in all subjects except English, but being a teacher I have a responsibility to mentor her. So the next step of motivation started, where I explained her that if she passes her engineering with flying colours, maybe she will have an option to pursue beautician course or else her parents will definitely marry her off. She thought for many days and as she was a witty child, she started concentrating on her studies and at present she is pursuing her MS in Canada and not yet married.

Conclusion - Teachers should forget the college hours and dwell deep into a student's problem to guide them.

\section{LIMITATIONS}

The cases which I discussed had their own limitations and may be some teachers might use some great strategy rather than the one used by me to enrich the students with the nuances and rules of English Language. In general, other students who are emotionally stable and eager to learn, there are various strategies to improve their LSRW skills like assignment writing, debate, group discussion, JAM session. I also advice my students to install a dictionary in their mobile which will help them to learn new words and finally they can construct proper sentence also. A teacher is actually a researcher in his/her class every day. Each and every day a teacher faces a new problem and they deal with it according to their knowledge and thought process. So to sum up motivation, conducive environment and task \& activities suitable for the learners is essential to fetch a student's attraction in learning a new language.

\section{ACKNOWLEDGEMENT}

To all the institutes where I served as Asst. Professor and my dear students.

\section{REFERENCE}

1]. Brown,Douglas.H. (2010) Principles of Language Learning and Teaching: Addission Wesley Longman, Pearson Education. 
2]. Dornyei, Zolatn.( 2009) "Motivation in Second and Foreign Language Learning". Cambridge Journals. Vol. XXXI.Issue.03.12 pp- 117-127.

3]. The English Journal,( 2007) Vol. 64, No. 9. (Dec., 1975), pp. 68-71.

4]. Naiman, N., Frohlich, M., Stern, H.H. and Todesco, (1978.)The Good Language Learner. Research in Education Series Ontario Institute for Studies in Education Press, Toronto:

5]. Saville-Troike, M. (1984). What really matters in second language learning for academic achievement? "TESOL Quarterly, (18)"2.

6]. Krishnaswamy.N.,Sriraman.T. (1991)English Language Teaching in India. T.R.Publications, Madras.

7]. Naime, Zahra . "Do You Know Where I Can Find the New Centre Which is called Cognitive Style and Language Learning Strategies Link ?.”

8]. H.H.Stern. (1991)Fundamental Concepts of Language Teaching. Oxford university press, Oxford.

9]. Sabatova, Jarmib.Bc.(2008) "Learning Strategies in ELT”.Diss. Masaryk University Brno.181.

10] Stern, H.H (1995). What can we learn from good language learner? Canadian Modern Language Review, 31, pp-304-318

11] McDonough Steven H. (1995) " Strategy and Skill in Learning a foreign Language". London, Edward Arnold

12]. Whitehead, J.M. (1984). Motivation for Higher Education: a study of intrinsic and extrinsic motivation in relation to academic achievement, Cambridge Journal of Education14, pp.26-3

13]. Nunan, David (1997). Strategy Training in the Language Classroom: An Empirical Investigation. In RELC Journal. Vol.28, No.2.

14]. Teacher Development an International Journal of Teachers' Professional development. Vol.7. pp:287-309

15]. Lessard, M-C (1997). Language Learning Strategies; an Overview for L2 Teachers. In Essays in Languages in Languages and Literature. Kwnasei Gakuin University,

16]. Nancy Cromer.(1975). Multi-Media: Why Should We Teach Multi-Media? 